\title{
Railway for Tourism in South America: An Approach on Its Uses
}

\author{
Thiago Allis ${ }^{1}$, Carla Fraga ${ }^{2}$ and Maximiliano Augusto Velazquez ${ }^{3}$ \\ 1. Department of Geography, Tourism and Humanities, Federal University of São Carlos, Sorocaba, São Paulo 18052-780, Brazil \\ 2. Department of Tourism and Heritage, Federal University of the State of Rio de Janeiro, Rio de Janeiro 22290-240, Brazil \\ 3. Center for Metropolitan Transportation Studies (CETAM), Universidad de Buenos Aires, City of Buenos Aires C1428EGA,
} Argentina

\begin{abstract}
In this paper, the authors focus on the interplay between railways and tourism. Therefore, evidence is provided in order to decipher the manner in which railways are used for tourism purposes in South America. With a view to achieving this goal, an exploratory approach is used, which consists in the analysis of publications on tourism and transportation made by renowned scholars, as well as a descriptive approach, based upon the classification of data obtained from public and private railway organizations. The paper notes that tourism is of paramount importance in the protection of the railway heritage in South America. Following this line of reasoning, it is concluded that there is a wide variety of tourist trains which exploit either the cultural and historical aspects of railways or the bewitching landscapes offered by railway trips and create experiences for tourists.
\end{abstract}

Key words: Transport, tourism, railways, South America, methodology.

\section{Introduction}

There is a strong association between railways and tourism: other than working as a tool for geographical distribution of tourist demand, connecting the point of departure of tourists and their destinations in one of the earliest tourism systems (for further details, see Ref. [1]), railways can enhance the image of particular tourist attractions, and acknowledge its cultural and heritage value, thereby contributing to the development of tourism. Not only is this true for tourist railways (special trains designed exclusively for tourist use), but also for train stations, railway workers' memories, and other physical and immaterial elements.

\footnotetext{
Corresponding author: Thiago Allis, Ph.D., professor, research fields: tourism mobility, urban tourism, tourism planning and post-conflict tourism. E-mail: thiagoallis@ufscar.br.

Carla Fraga, adjunct professor, research fields: railway tourism and transportation engineering. E-mail: carlota.fraga@gmail.com.

Maximiliano Augusto Velazquez, professor, research fields: urban and regional planning, information technology and urban mobility. E-mail: maxovelazquez@gmail.com.
}

South American countries share some common aspects in their history of the establishment (after mid-19th century), development and obsolescence (20th century) of railways. This led, in recent decades, to initiatives aimed at valorizing railway heritage for tourism purposes. While it is uncertain what the future holds for railways as a means of transportation in most of these countries, the possibilities for tourist activities point toward a vibrant scenario for railway systems nowadays, in particular, regarding the conservation and valorization of the railway heritage for tourism uses. It is worth mentioning, however, that in spite of the historical, political and economic similarities within the region, comparative studies are rare, and tourism and tourist uses of railways are no exception.

Thus, the purpose of this paper is to understand the use of railways for tourism in South America, using both an exploratory and descriptive approach and a qualitative emphasis, by taking into consideration discussions on specific literature of tourism and transportation, as well as data available at public and 
private railway entities (including those in charge of the management of tourist trains within the subcontinent). We believe that this contribution is part of a comprehensive approach whose ultimate end is to add value to the South American railway heritage, by focusing on meaningful tourist developments in particular regions within this subcontinent.

\section{Setting the Stage: Railways and Tourism in South America}

Despite its inherent "usefulness", transportation can also play its part in tourism development, taking into consideration its "intrinsic value as an experience"-this is illustrated by the so called tourist railways, which have both a nostalgic and/or scenic appeal [2]. In the case of rail transportation, it should be noted that railways are intertwined with tourism in two ways: (1) geographic sprawl of demand flows within a given region; and (2) railway experience as a tourist experience in itself [3-5]. Even though this tourism product is available in a large number of countries-for example, in Britain, there are more than 140 tourist trains in operation [2], this sort of rail service could represent a unique opportunity for tourists to engage in a railway experience, considering that in many places all over the world, it has been replaced by other transportation modes, mainly roads. This is true of most South American countries, with few exceptions in Brazil, Chile and Argentina, where regular services are still in operation, albeit of very low quality.

Additionally, other connections between different elements related to railway culture, both material and immaterial, could be pointed out. Let us mention, for example, the refurbishment of old and obsolete buildings as museums, libraries or commercial premises, when this occurs the function of one of the components of the railway system (i.e., the original terminal) is metamorphosed into a new one (the fruition of the railway ambience itself). Moreover, regarding the way (i.e., the trackbed), some outstanding experiments have been implemented throughout the world, namely the Spanish "Vías Verdes” program whereby an NGO (non government organization), in cooperation with partners and individual supporters, aims to implement cycle routes on out-of-service rail tracks to promote tourism, among other goals; to date, more than 1,242 miles of these ways have been restored, equipped with signage and opened up for public use [6].

It is important to underline that, by railway tourism, we understand all activities embedded in a tourist experience undertaken by tourists in search of multiple aspects of railway culture, whether in motion (for instance, nostalgic/scenic tourist trains, special services in a regular railway or even the pleasure of traveling in a conventional railway) or not, when the components of the system provide, in separate, memorable tourist experiences (railway museums, visits to train stations, food services in old passenger cars).

In South America, where the first railway ran in 1851 from Lima to Callao, Peru, covering a distance of 8.6 miles [7], the railways basically provide services for exportation of raw material [8]. After a construction peak in late 19th century and in the first decades of the 20th century, the quality and efficiency of railways in almost all countries went into a steep decline, leading to a wave of nationalization in an attempt to recover government participation in the rail operations or to keep the passenger services. At the same time, and in line with the emergence of the automobile culture, railways came to be considered as an archaic solution. Some efforts were made in Brazil, after the 1990s — when railways were privatized — but outcomes were more visible in freight transportation (nowadays, almost $30 \%$ of the goods are transported by railway, especially iron and soy beans), though three regional trains provide passenger services-i.e., not tourist trains-in medium and large distances [9]. As far as Argentina is concerned, the system was privatized almost in the same period and passenger services, 
which were outdated and faced an impending risk of accident, remained under the control of the provinces. In the case of Chile, a few train lines provide both regular services for passengers and tourism services.

In that context, notwithstanding the fact that the train has played a key role in almost all countries within the region (mainly in Brazil, Argentina, Chile, Peru and Colombia, just to name a few), it is possible to affirm that today being on a train is not part of our travel routines-except for metropolitan trains and subways in major cities (São Paulo, Rio de Janeiro, Buenos Aires, Santiago, Caracas, etc.) and a few remaining passenger lines. Then, the opportunity of embarking on a train experience is mainly reserved for tourist trains, whose purpose is to provide special transport services for tourists-therefore speed and ticket price (reasonability) are not the driven forces.

On the other hand, railway operational assets were not totally extinguished and they have acquired a new status as cultural heritage. Consequently, they can be adopted by contemporary tourism plans in order to feed a wide array of tourist demands. It is possible to observe different behavior among tourists interested in railways, while some look for cultural attributes (architecture, history, memories related to railways), others are keen on the scenic issues-e.g., panoramic train to Christ The Redeemer (Estrada de Ferro do Corcovado), in Rio de Janeiro, which runs into the rainforest of Tijuca National Park.

If tourist profile analysis-concerning those groups with particular interest in railways — were to be applied to tourism planning and public policies, it could be instrumental in increasing the output or the tourism sector. For example, the concept of "railfans" sheds light in a field that clearly opens space for a proper assessment of tourism and railways, regarding tourist behavior and demography [10].

Over the last 30 years, we have witnessed the flourishing of tourist trains all over the world, not only in countries where railways were banished, but also in those where, even today, railways have been vital for logistics and passenger transportation (such as Britain, Switzerland, Germany, etc.). In South America, railway tourism relies particularly on a diverse, though fragmented, set of tourist railways, both for those who experience nostalgia for steam trains and for those who take pleasure in panoramic tours (regardless of the technology).

According to the UNWTO (United Nations World Tourism Organization), almost $40 \%$ of international arrivals in the Americas in 2012 were by land [11]. Nonetheless, it should be underscored that on account of the poor level of railway trans-border connections in the region, compared to road links, there are few opportunities for railway trips. Different gauges are but one reason for the scarcity of railway passenger services. It should also be borne in mind that much importance was attached to investment in other modes, such as road, mainly after mid-20th century.

\section{Research Methods}

A bibliographic review was used as a tool for exploratory research in order to establish the conceptual framework of this study. Concerning the empirical approach, data were summarized in two main data categories, in line with the basic needs for the organization of railway tourism, as follows: (1) operation: relationship between tourism, territory and railways in terms of origin/destination (points) and the railway itself (vectors); (2) planning: types of management, public policies, as well as themes underlying these tourism products.

The parameters of evaluation have been set according to previous studies on the relationship between railways and tourism [3-5, 12, 13]. In addition to the variables listed in Table 1 , every tourist train/railway has been labeled according to country of origin, name of operator, route (origin/destination).

Yet both dimensions ("operation” and "planning”) are intertwined, therefore they should not be split. The importance of setting these criteria and variables lies in the fact that they help to visualize the preliminary 
Table 1 Research framework-tourist trains in South America.

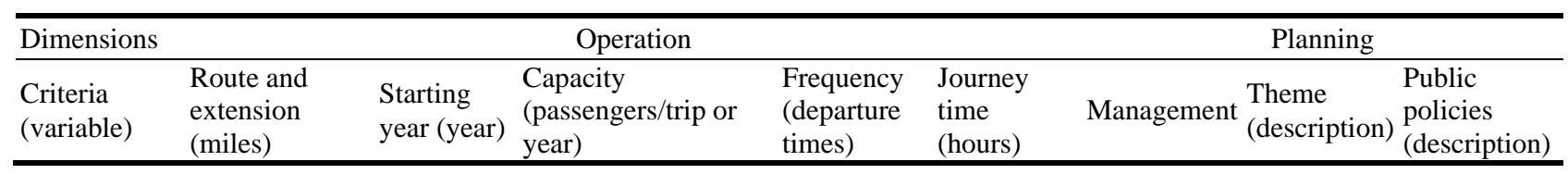

Source: prepared by the authors.

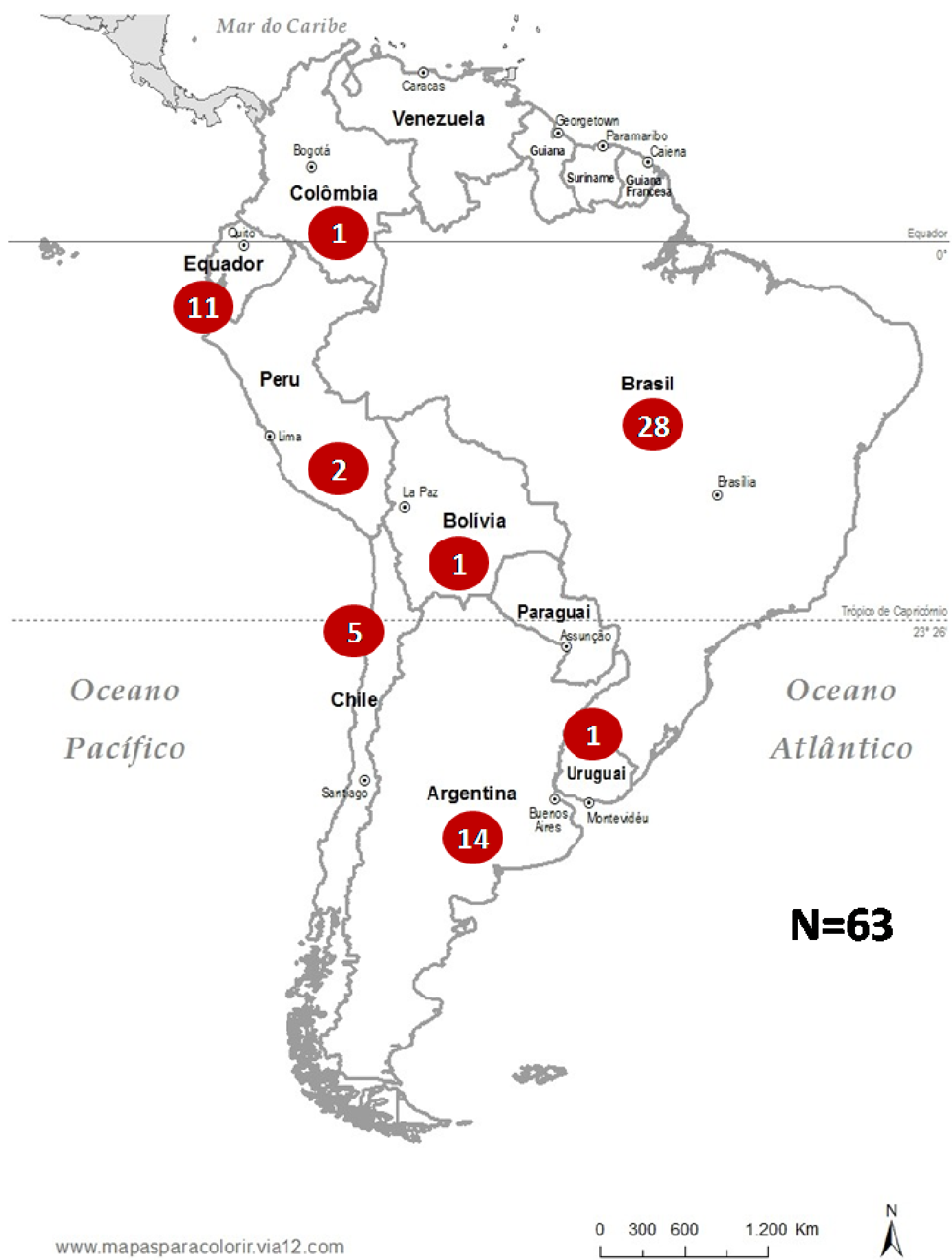

Fig. 1 Number of tourist trains per country-South America.

Source: prepared by the authors with data from tourist train operators (www.mapasparacolorir.com.br). 
considerations on the topic (tourism vs. railways). The aim was to carry out a broad data collection of tourist railways in South America; nevertheless, it cannot be assumed that the cases $(N=63)$ represent the totality of the current initiatives. In any case, as per the vast research undertaken on websites and in accordance with the authors' remarks from previous works, it is possible to assert that it comprises a considerable portion of tourist railways in operation in South America.

\section{Results and Discussions}

Fig. 1 shows that $66.6 \%$ of all cases $(N=63)$ are located in Argentina and Brazil, followed by Ecuador and Chile. Despite the fact that Peru offers only two services, they are an illustration of widely appealing tourism products in the region.

In the following sections, the criteria and variables presented in Table 1 are analyzed. Nonetheless, before embarking ourselves into such analysis, it is worth pointing out that: (1) the universe of tourist resources attached to railways in South America is enormous, then accurate information available may vary, leading to possible inconsistencies; (2) to date, it is not possible to carry out a comprehensive analysis of all tourist train features shown in Fig. 1, however, we can observe roughly recurrent characteristics, which are deemed enough to make preliminary assumptions on the topic. Then, the remarks that shall hereafter be made on each topic do not necessary claim the same level of accuracy for all tourist trains, since, as mentioned above, we have yet to gather enough information on all trains regarding the same variables and criteria (Table 1). This is certainly a project that we shall undertake in the near future.

\subsection{Route and Extension}

The longest train routes for tourist purposes are “Tren Patagónico", in Argentina, between Viedma and San Carlos de Bariloche (510 miles), and "Tren Crucero” (279 miles), in Ecuador, connecting Quito and Guayaquil within 4 days, with overnight stays in midway stops. These services, usually one-way only, require tourists to use other modes of transportation after the railway experience.

Other trains provide circular services, i.e., roundtrip excursions by train (or by train and bus), with variable distances, including cultural and/or outdoor activities within the program. These are the cases of "Tren Turístico de la Sabana” (Colombia) and "La Trochita" (Argentina).

The assessment of shorter services showed that some trains can be considered as attractions of particular destinations, such as the "Trem do Imigrante" (1.86 miles one-way), which is part of the tour at the Immigrants' Memorial in São Paulo, and the "Trem do Corcovado" (2.36 miles one-way), offering access to the world-famous Christ the Redeemer statue in Rio de Janeiro, both in Brazil. For its part, the "Tren del Fin del Mundo" and the "Tren Ecológico de la Selva”, in Argentina, also provide very short excursions-roughly 4.35 miles-in the framework of outdoor and cultural tourist activities in Ushuaia and in the Iguazú National Park, respectively.

In any case, these train services are paramount for tourism development in regions or destinations where railways are a current legacy from past periods. Nowadays, they add up to the attractions in particular tourist destinations/regions, and operate in coordination with other elements of the tourism industry.

The link between rail and tourism in the particular case of Argentina can be traced back to the early 20th century. As the railroad was extended, some hotels that exploited the benefits of thermal water and the magnificence of key landscapes in the country were built [14]. One case that deserves special attention is the seaside city of Mar del Plata, on the Atlantic coast of the province of Buenos Aires: with the arrival of the railroad to this seaside city important changes took place, which helped it to achieve its goal of becoming the main tourist center in the country. A similar movement occurred in Brazil, at Desvio Blauth, 
Veraneio Hampel and Pelotas, all early tourist destinations in the state of Rio Grande do Sul [4, 15].

\subsection{Starting Year}

With few exceptions (e.g., "Trem do Corcovado” in Brazil), major tourist trains identified were put into service after the 1990s. This illustrates a recent trend of commercial valorization of this heritage, whose ultimate purpose is to recover the experience of traveling by trains. This is remarkable in an era where almost all countries within the region have closed down regular passenger services. For instance, in Argentina, "La Trochita” (province of Río Negro) was inaugurated in 2014 and, in Brazil, "Trem das Montanhas Capixabas”, in 2010.

Furthermore, it is essential to underline the issue of the intermittency of services (note, however, that it was not deeply assessed in this work): in some cases, in particular where the service is managed by independent associations, important variations in schedule planning and execution may occur due to poor management strategies or insufficient financial resources. On the other hand, tourist trains (e.g., Peru Rail in Peru and Serra Verde Express in Brazil) managed by private corporations tend to be more solid tourism products, since its owners are keen on long term financial issues.

\subsection{Capacity and Frequency}

The volume of passengers certainly varies according to the trains' capacity and the frequency of the services. Detailed information (whether official or not) on both availability of seats (capacity of each train/composition) and service frequency (number of trips per month/year) has not been identified, making it difficult to determine the overall volume of passengers.

The Brazilian Association of Railway Preservation [16] gathers and makes available data on some tourist trains in Brazil, however, the quality of the information varies according to the accuracy of the data collection process undertaken by each local operation. For example, it reported that “Trem das Águas” carried
32,000 passengers and "Viação Férrea Campinas-Jaguariúna”, 78,000, however it did not provide the year of the data [17].

According to the website of "Trem do Corcovado", it carries an outstanding number of passengers (over 600,000 per year), since it is part of Rio de Janeiro's tourism facilities. Similarly, “Tren de la Costa”, in Buenos Aires (Argentina) carried almost 650,000 passengers in 2014-although this service links multiple destinations within Buenos Aires Metropolitan Area.

When trains have a low seat capacity and make few departures, they transport a small number of tourists per year, in other words, they have a reduced operating capacity. This could be related to the necessity of preservation/conservation of old passenger cars and centennial steam machines. On the other hand, trains powered by diesel/electric locomotives-and, in general, with more seats available-carry more passengers per year, for this reason they are considered mass tourism products, even if they conjure up, directly and indirectly, railway heritage values.

On the subject of the frequency of departures, it should be mentioned that few services run daily. In general, tourist trains run on weekends, holidays or even on specific dates (once or twice a month). This is an evident feature of tourist trains, which confirms that they run on "tourist" demand: by providing services to tourists (or to passengers in their leisure time), some concentration is expected on those days, given the fact that most local/regional tourists make short-distance trips. Unlike those initiatives, PeruRail (Peru) and “Trem do Corcovado” (Rio de Janeiro, Brazil) operate in a very busy tourist region/destination, justifying its daily frequency (or multiple departures per day), irrespective of the length of the trips. Yet, some tourist trains operate only under specific demands, with charter services for groups, events, etc.

\subsection{Management}

It is possible to observe a proportional balance 
between public and private organizations in charge of tourist trains in South America. In Argentina, where most trains are managed by the public sector, the primary responsibility for its operation usually falls into the hands of provincial governments (or its divisions). Whereas in Brazil, in addition to public and private initiatives, independent organizations also play a crucial role, with great engagement of the Railway Preservation Brazilian Association [16] , supported by local branches, which is responsible for tourist trains in many states within the country. In Peru, PeruRail is emblematic for having been in charge, over the last 15 years, of the management of local trains, making them a highly appealing tourist attraction in the region-which is extremely busy and internationally renowned. In that sense, there are some grounds to believe that the decision of Orient Express Co. to engage in such project is explained by the prospective revenues derived from the operation of train services in a very dynamic tourist region in Peru-and not necessarily because of the value of railway heritage. Likewise, Ecuador's train services (“Tren Crucero" and all 10 variations of “Tren Ecuador"), directly managed by the national government, deliver high quality and diverse tourist experiences in the line Quito-Guayaquil, which includes partnerships with local communities for the operation of "Cafés del Tren”, available in midway stops along the railway.

\subsection{Theme}

Broadly speaking, it may be assumed that tourist trains are alluring on two bases: (1) valorization and fruition of its cultural heritage (both material and immaterial); and (2) contact with natural landscapes, provided by the scenic routes, as proposed by Palhares [18]: "nostalgic" and "scenic" trains.

Tourist trains with old compositions (steam locomotives and wooden passenger cars) tend to prioritize cultural elements on its journey (as observed in many trains in Argentina, Brazil, Chile, and, on a smaller scale, Ecuador). Conversely, when compositions are more recent-and routes are longer - the appeal tends to be the landscape and other local attractions in the communities visited along the way.

From our perspective, both cultural and natural attractions should be taken jointly, since it is neither possible nor desirable to draw a line between them when considering railways as tourist experiences. Trains in Ecuador are good illustration of this symbiosis: the goal of the tour is to enhance cultural experiences in the communities visited, and at the same time, highlight the magnificence of the Andean and other landscapes. In other cases, the journey in itself is more important than any other aspect-like in "Trem do Forró,” in Brazil, where 'forró', a typical rhythm performed along the way, is at the core of the train experience, rather than any other "rail subject".

It is clear that tourist trains-or the so called "railway tourism"-can attract several market segments such as cultural tourism (e.g., steam locomotive tours), but also event tourism, luxury tourism (“Trem do Luxo", in Brazil), etc., as discussed by Fraga [5].

\subsection{Public Policies}

Since Brazil and Argentina account for almost 70\% of all tourist trains in the region, it seems that more public policies regarding the interaction between trains and tourism emerge in these countries.

The Brazilian Ministry of Tourism classifies almost all tourist trains identified in this work as tourist attractions. Furthermore, a guidebook released in 2010 provides guidelines for the establishment of new tourist trains, this is but one of the results of a joint commission of ministries, associations, etc., concerned with the development of railway tourism. In Argentina, half of the 14 tourist trains in service are part of provincial tourism plans-two of them in Río Negro Province. Additionally, the Five-Year Railway Operational Plan (2016/2020) encompasses some of these trains, which clearly points out the government's 
concern over tourism in the framework of transportation planning.

It may be argued that tourist trains play a role in the tourism development process of the region, which includes adding some visibility on farther outbound markets. In Peru and, to some extent, in Colombia (“Tren Turístico de la Sabana”), tourist trains boost tourism not only in the regions where they operate, but also in South America at large (since overseas tourists tend to make a regional circuit when visiting the subcontinent). For instance, in Ecuador, “Tren Crucero" has been awarded a certificate of excellence by Trip Advisor in 2014, as the "Leading Luxury Train in South America”.

Additionally, some services in Argentina, Brazil, Bolivia and Uruguay make their contributions to their respective national tourism industry, this, however, may be less apparent for international observers. Nevertheless, detailed (and comparative) studies are to be done in order to fully understand the importance of these trains in the regional tourism development, regarding both sub-national policies and the engagement of other stakeholders.

\subsection{Fares}

The more elaborated the product, the more diverse facilities associated to it are, resulting in a broad range of prices. In accordance with the extension, diversity and level of services, prices range from modest fares (mainly for the less promoted trains, like in Bolivia and Uruguay) to expensive ones, for more extravagant services ("Tren Crucero”, “Hiram Bingham” of PeruRail and “Trem de Luxo”, in Brazil).

In general, prices are reasonable (roughly US\$20), making these trains competitive and viable in the context of other regular services. Most tourist trains identified in this study offer reduced fares for children, elderly people and, occasionally, students, in accordance with national regulations or commercial strategies, irrespective of the type of organization in charge of the train. PeruRail, for instance, delivers a "social service" to communities not served by other modes of transportation.

\subsection{Journey Time}

Most train trips are same-day services, the round trip takes up to 4 hours, though some depart early in morning and return in the evening (5-10 hours)—like “Tren a las Nubes”, in the Province of Salta, and the overnight service to Bariloche offered by the "Tren Patagónico”, both in Argentina. “Tren Crucero” in Ecuador is an exception, with a journey of up to 4 nights; nonetheless, it also offers 10 different services that take no more than a few hours.

This issue deserves further research, especially from the viewpoint of the tourist experience, since, as mentioned earlier, most of these trains are part of a tour in a particular destination, then it should be elucidated whether "tourist trains" are currently perceived as one-day attractions. As a consequence, if a regional tourism development plan is to suggest an integration of other communities - with a more complex tourism program, including multiple-destination trips, it is critical to understand if and how future tourists would (or would not) engage in such scheme.

\section{Conclusions}

Even though the 63 tourist trains presented here do not represent the totality of tourist railway services in South America, this offers a significant portrait to lay the foundation for future debates on their importance for tourism development in the region. Given the rich railway past of almost all countries (most of them not served by regular railway passenger services at present), it did not come as a surprise that a large number of initiatives had emerged over the last 20 years. In this regard, it is important to underscore that even when most of such tourist trains are powered by nostalgic steam locomotives, the visitor in search of rail experiences in South America will run into a multiplicity of cultural, historical and landscape aspects embedded in each initiative. Consequently, 
tourist trains-as tourism products-are very heterogeneous, due to contextual particularities, notwithstanding the fact that the railway culture per se (material and immaterial) provides an equal ground for any initiative.

In conclusion, the role of tourism in the preservation of the railway heritage in South America is undeniable, although investments in planning and management (including promotion, branding, pricing strategies) as well as public policies (both domestic and South-American as a whole) have yet to be detailed. By doing so, several countries in the continent will bring to light the potential benefits of railway tourism development.

In this line, future research could focus on demand profile studies, taking into account preliminary assumptions presented in this work and pushing the boundaries of both knowledge and practices in railway tourism in South America.

\section{References}

[1] Leiper, N. 1990. “Tourist Attractions Systems.” Annals of Tourism Research 17 (3): 367-84.

[2] Hall, D. 2008. "Transport, Tourism and Leisure." In Transport Geographies: Mobilities, Flows and Spaces, edited by Knowles, R., Shaw, J., and Docherty, I. Malden: Blackwell, 196-211.

[3] Allis, T. 2002. "Ferrovia e Turismo Cultural: Uma Alternativa para o Futuro da Vila de Paranapiacaba." Turismo em Análise 13: 29-53. Accessed August 1, 2015. http://www.revistas.usp.br/rta/article/view/63597. (in Portuguese)

[4] Brambatti, L. E., and Allis, T. 2010. Trens e turismo: as origens de Desvio Blauth e Verenaio Hampel. 1st ed. Santa Maria: Meridiano. (in Portuguese)

[5] Fraga, C. C. L. 2011. "Contribuição Metodológica para a Implantação de Trens Turísticos no Brasil.” Doctoral thesis, Universidade Federal do Rio de Janeiro, Rio de Janeiro, Brazil. Accessed August 1, 2015. http://www.pet.coppe.ufrj.br/index.php/producao/teses-de -dsc/doc_details/212-contribuicao-metodologica-para-a-i mplantacao-de-trens-turisticos-no-brasil-. (in Portuguese)

[6] Vías Verdes. n.d. Homepage. Vías Verdes. Accessed August 1, 2015. http://www.viasverdes.com.
[7] Santos, R. A. 2013. "Expansão da Malha Ferroviária Brasileira e Sul-Americana para o Desenvolvimento e Integração Regional, com Prioridade nas Expressões Econômica e Militar-Reflexos na Mobilização Nacional.” Caderno de Estudos Estratégicos de Logística e Mobilidade Nacional 1 (4): 196-216. (in Portuguese)

[8] Lacerda, S. M. 2009. "Ferroviais Sul-Americanas: a Integracão Possível.” Revista do BNDES, Rio de Janeiro 16 (31): 185-214. (in Portuguese)

[9] Agência Nacional de Transportes Terrestres, Ferroviário. 2013. Accessed August 1, 2015. http://www.antt.gov.br/ index.php/content/view/4741.htm. (in Portuguese)

[10] Stefanovic, K., and Koster, R. 2014. "Railfans and Railway Heritage Tourism.” In Railway Heritage and Tourism: Global Perspectives, edited by Conlin, M. V., and Bird, G. R. Bristol: Channel View Publications.

[11] World Tourism Organization. 2013. Tourism in the Americas. 2013 Edition. UNWTO.

[12] Allis, T. 2006. "Turismo, Patrimônio Cultural e Transporte Ferroviário: um Estudo Sobre Ferrovias turíSticas no Brasil e na Argentina.” Masters' thesis, Universidade de São Paulo, São Paulo, Brazil. Accessed August 1, 2015. http://www.teses.usp.br/teses/disponiveis/84/84131/tde-1 1092007-112140/pt-br.php. (in Portuguese)

[13] Fraga, C. C. L., Santos, M. P. S., and Ribeiro, S. C. 2014. "Railroad Tourism in Brazil." In Railway Heritage and Tourism: Global Perspectives, edited by Conlin, M. V., and Bird, G. R. Bristol: Channel View Publications.

[14] Gonzalez,V. A. 2003. "Trenes Turísticos, La Puesta en Valor del Ferrocarril Argentino Luego de su prIvatización.” Ph.D. thesis, Universidad Nacional de Mar del Plata, Mar del Plata. (in Portuguese)

[15] Müller, D. 2013. “'Viagens de Recreio’: Primeiras Manifestações do Turismo em Pelotas/RS.” In História do turismo no Brasil, edited by Castro, C., Guimarães, V. L., and Magalhães, A. M. Rio de Janeiro: FGV, 147-64. (in Portuguese)

[16] ABPF (Associação Brasileira de Preservação Ferroviária). n.d. Accessed August 1, 2015. http://www.abpf.com. br/inicio/. (in Portuguese)

[17] Ministério do Turismo, Brasil. n.d. "Trens turísticos em operação no Brasil.” Accessed August 1, 2015. http://bit.ly/1JvWGV1. (in Portuguese)

[18] Palhares, G. L. 2002. “Transportes Turísticos.” Caderno Virtual de Turismo 2 (4). Accessed August 1, 2015. http://www.redalyc.org/pdf/1154/115418121004.pdf. (in Portuguese) 


\section{Appendix 1 Tourist Railway Websites}

1. АВОтТС, Associação Brasileira das Operadoras de Trens Turísticos Culturais, available online at: http://www.abottc.com.br/guia_lista.aspx, accessed August, 2015.

2. Corcovado, História e curiosidades, available online at: http://www.corcovado.com.br/portugues/historia.html.

3. Tren Ecuador, Tren Crucero, available online at: http://trenecuador.com/crucero/es/, accessed August, 2015.

4. Tren Ecuador, Tren Ecuador, available online at: http://trenecuador.com/, accessed August, 2015.

5. Tren Turístico de la Sabana, Tren Turístico de la Sabana, available online at: www.turistren.com.co, accessed August, 2015.

6. Empresa Ferroviaria Andina, Tren Turístico a Guaqui, available online at: http://www.fca.com.bo/subcontenido.php?seccion =2\&subseccion=41\&subcontenido=18, accessed August, 2015.

7. Peru Rail, Peru Rail, available online at: www.perurail.com/es, accessed August, 2015.

8. Trenes a Vapor, Tren a Vapor Peñarol, available online at: www.trenesavapor.com, accessed August, 2015.

9. Tren del Recuerdo, Tren del Recuerdo, available online at: www.trendelrecuerdo.cl, accessed August, 2015.

10. Museo Ferroviario Temuco, Tren de la Araucanía, available online at: http://www.museoferroviariotemuco.cl/2tren/1 presentacion.html, accessed August, 2015.

11. Chile en Tren, Góndola Carril, available online at: http://chilentren.cl/gondola-carril/, accessed August, 2015.

12. Chile en Tren. Tren Valdiviano, available online at: http://chilentren.cl/el-valdiviano/, accessed August, 2015.

13. Tren Central, Tren Sabores del Valles, available online at: http://www.trencentral.cl/link.cgi/servicios/tren-valle-colchagua, accessed August, 2015.

14. Serra Verde Express, Trem das Montanhas Capixabas, available online at: http://www.serraverdeexpress.com.br/site/ conheca.aspx?cod=8, accessed August, 2015.

15. ABPF Regional Sul de Minas, Trem das Águas, available online at: http://abpfsuldeminas.com/trem-das-aguas/, accessed August, 2015.

16. Centro de Referência Ambiental e Turística, Trem das Cachoeiras, available online at: http://www.crat.com.br/news/?id=68, accessed August, 2015.

17. ABPF Regional Sul de Minas, Trem da Serra da Mantiqueira, available online at: http://abpfsuldeminas.com/ trem-da-serra-da-mantiqueira/, accessed August, 2015.

18. Trem do Forró, Trem do Forró, available online at: www.tremdoforro.com.br, accessed August, 2015.

19. Serra Verde Express, Serra Verde Express, available online at: http://www.serraverdeexpress.com.br/site/conheca.aspx?cod=13, accessed August, 2015.

20. Trem do Corcovado, Trem do Corcovado, available online at: www.corcovado.com.br, accessed August, 2015.

21. Giordani Turismo, Trem da Serra Gaúcha, available online at: http://giordaniturismo.tempsite.ws/mfumaca/default.html, accessed August, 2015.

22. ABPF Regional Sul de Minas, Trem das Águas, Trem das Termas, available online at: http://abpfsc.com.br/web/piratuba/, accessed August, 2015.

23. ABPF Regional Sul de Minas, Estrada de Ferro Santa Catarina, available online at: http://abpfsc.com.br/web/apiuna/, accessed August, 2015.

24. ABPF Regional Sul de Minas, Trem da Serra do Mar, available online at: http://abpfsc.com.br/web/rionegrinho/, accessed August, 2015.

25. Prefeitura Municipal da Estancia Turistica de Paraguaçu Paulista, Trem Moita Bonita, available online at: http://www.eparaguacu. sp.gov.br/mariafumaca.asp, accessed August, 2015.

26. ABPF Regional Sul de Minas, Trem do Imigrante, available online at: http://www.abpfsp.com.br/passeio_trem.htm, accessed August, 2015.

27. ABPF Regional Sul de Minas, Trem dos Ingleses, available online at: http://www.abpfsp.com.br/passeio_trem.htm, accessed August, 2015.

28. ABPF Regional Campinas, ViaIção Férrea Campinas -Jaguariúna, available online at: http://www.mariafumacacampinas.com.br/, accessed August, 2015.

28. Vale, Ouro Preto-Mariana, available online at: http://www.vale.com/brasil/PT/business/logistics/railways/trem-turisticoouro-preto-mariana/Paginas/default.aspx, accessed August, 2015.

29. Trilhos de Minas, São João Del Rei a Tiradentes, available online at: http://trilhosdeminas.com/, accessed August, 2015.

30. Serra Verde Express, Trem de Luxo (Great Brazil Express), available online at: http://www.serraverdeexpress.com.br/site/ conheca.aspx?cod=23, accessed August, 2015. 
31. Serviço Social do Comércio, SESC de Grissaí, available online at: http://www.sescmg.com.br/wps/portal/sescmg/unidades/ hospedagem/sesc_mineiro_grussai, accessed August, 2015.

32. Estrada de Ferro Campos do Jordão, Estrada de Ferro Campos do Jordão, available online at: http://www.efcj.sp.gov.br, accessed August, 2015.

33. Companhia Paulista de Trens Metropolitanos, Estação da Luz/Paranapiacaba, available online at: www.cptm.sp.gov.br, accessed August, 2015.

34. Companhia Paulista de Trens Metropolitanos, Estação da Luz/Jundiaí, available online at: www.cptm.sp.gov.br, accessed August, 2015.

35. Companhia Paulista de Trens Metropolitanos, Estação da Luz/Mogi das Cruzes, available online at: www.cptm.sp.gov.br, accessed August, 2015.

36. Turismo Villa Elisa, Trencito de Villa Elisa, available online at: http://www.turismovillaelisa.com.ar/tren.htm, accessed August, 2015.

37. Travesía de Ubajay, Travesía de Ubajay, available online at: https://www.facebook.com/museo.ubajay, accessed August, 2015.

38. Ferrobaires, Tren Turístico Tandil-Gardey-Vela, available online at: http://www.ferrobaires.gba.gov.ar/ferrobaires/web/index.php /1/550/destacados/tren-turistico-tandil-gardey-vela, accessed August, 2015.

39. Patagonia Express, La Trochita, available online at: http://www.patagoniaexpress.com/el_trochita.htm, accessed August, 2015.

40. Tren del Fin del Mundo, Tren del Fin del Mundo, available online at: http://www.trendelfindelmundo.com.ar, accessed August, 2015.

41. Río Negro, La Trochita (Río Negro), available online at: http://www.rionegro.com.ar/diario/la-trochita-volvio-a-rodar-4774 002-53285-nota_cordillera.aspx, accessed August, 2015.

42. Tren a las Nubes. Tren de las Nubes, available online at: http://www.trenalasnubes.com.ar, accessed August, 2015.

43. Tren Histórico a Vapor, Tren Histórico a Vapor, available online at: http://www.trenhistoricoavapor.com/tren.htm, accessed August, 2015.

44. Iguazú Argentina, Tren Ecológico de la Selva, available online at: http://www.iguazuargentina.com/en/que-hacer/10-cosaspara-hacer/tren-ecologico-de-la-selva, accessed August, 2015.

45. Operadora Ferroviaria Sociedad del Estado, Tren de la Costa, available online at: https://www.sofse.gob.ar/servicios/horarios-trencosta.php, accessed August, 2015.

46. Operadora Ferroviaria Sociedad del Estado, Tren de las Sierras, available online at: https://www.sofse.gob.ar/servicios/horariosregionales-cordoba.php, accessed August, 2015.

47. Tren Patagónico S.A., Tren Patagónico, available online at: http://www.trenpatagonico-sa.com.ar/esp/index_2.html\#, accessed August, 2015.

48. Visiting Argentina, Piedra Baya, available online at: http://www.visitingargentina.com/piedra-baya-ferrocarril-de-montana/, accessed August, 2015.

49. Ferroclub Argentino, Tren Histórico del Ferroclub Argentino, available online at: http://www.ferroclub.org.ar/eventos.html, accessed August, 2015. 